\title{
Biodiversity of Spiders Associated with Cotton and Maize in Sharkia Governorate with a Special Reference to the Spider, Kochiura aulica (Koch)
}

\author{
Gihan, M.E. Sallam, Nahla A.I. Abdel Azeim, H.M.G. El-Kawas \\ Plant Protection Research Institute, Agricultural Research Center, Dokki, Giza, Egypt
}

(Received: July 7, 2010)

\begin{abstract}
Spiders associated with cotton and maize plants were recorded in Sharkia Governorate, Egypt, during 2009 season: Results revealed the occurrence of eighteen spider species belonging to nine families. Eight and sixteen species were collected from cotton and maize plants, respectively. Thomisus spinifer Cambridge was the most frequent species, with 100.00 and $20.45 \%$ for absolute frequency and relative frequency of occurrence, respectively, while all Erigone sp., Gnathonarium dentatum (Wider), Euryopis sp., and Cyrtophora citricola (Forskal) recorded the lowest frequency occurrence 5.5 and $1.13 \%$, respectively. Life cycle and female fecundity of Kochiura aulica (Koch) (Theridiidae) were studied when fed on Spodoptera littorals (Boisd.) second instar larvae. Feeding capacity was also estimated. Obtained data cleared that $K$. aulica can be used as a biocontrol agent in integrated pest management program.
\end{abstract}

Key Words: Spiders, Biodiversity, Life cycle, Kochiura aulica, Maize, Cotton.

\section{INTRODUCTION}

Spiders are arachnids of widespread occurrence in nature feeding voraciously on other arthropods i.e., small insects and phytophagous mites. More than 30.000 spider species existed worldwide (Nyffeler et al. (1994). Spiders may play an important role in controlling field populations of economic agricultural pests infesting some important crops. Kamal et al., (1995), Asin \& Pons, (1996) and Rahil 2001, revealed spiders potentials to feed on hemipteran, homopteran, lepidopteran and thysanopteran insects reducing their damage. Due to their presence in large numbers and capabilities to capture the prey, spiders inhabit certain crops can be considered as potentially biocontrol agents.

Araneida consists of 109 families of spiders; of which the family Theridiidae occupies the fifth rank from six familics its number of species exceeds 2.000 species. It includes 2297 species belonging to 112 genera (Platnick 2010). One species of the genus Kochitura Archer is recorded, among 25 species of 10 genera of Theridiidae, in Egypt (ElHennawy 2002 \& 2006). Kochiura aulica (Koch) was collected from Alexandria. Nile Delta. Siwa Oasis and Wadi Natron, Egypt (El-Hennawy 2006). The first successful mass rearing and the observation of the sociality behavior were proved under laboratory condition by Abdel-Karim et al., (2006).

The purpose of the present study is to provide information on incidence of spiders community associated with the two crops: cotton Gossypium barbadense L. and maize Zeu mans L. in Sharkia Governorate, Egypt. Life cycle of the spider species,
$K$. aulica (Koch) was also studied when feed on the second instar larvae of the cotton leafworm, Spodoptera littoralis (Boisd.).

\section{MATERIALS AND METHODS}

\section{Ecological studies:}

The present study was carried out on cotton G. barbadense variety Giza 86 and maize Z. mays cultivated in Sharkia Governorate, Egypt during 2009 season. Spiders were collected randomly using beating net, plant shaking and hand sorting every 15 days from $1^{\text {st }}$ May to $15^{\text {th }}$ September (nine samples for each crop).

The collected spiders were preserved in $70 \%$ ethanol for classification.

\section{Statistical analysis:}

The occurrence of collected spiders on each crop was analyzed using two ecological parameters. There were percentages of absolute and relative frequency occurrence according to Norton (1978) as follows:

\section{Absolute frequency of occurrence $=$ \\ Number of samples containing species Number of collected samples X 100}

Relative frequency of occurrence $=$

Absolute frequency occurrence of a species Sum absolute frequency occurrence of all species $\times 100$

\section{Rearing technique of spider, $K$. aulica:}

Gravid females of $K$ aulica were placed in translucent plastic vials $(2 \mathrm{~cm}$ diameter and $5 \mathrm{~cm}$ high), supplied with $2^{\text {nd }}$ instar larvac of $S$ littorcalis 
as prey, closed with musline and kept under laboratory conditions $\left(28 \pm 1{ }^{\circ} \mathrm{C} \& 60-70 \%\right.$ R.H.) to start a pure culture of the spider. Twenty newly hatched spiderlings were transferred singly to the rearing vials; each one was supplied with a known number of prey during investigation. Devoured prey were recorded and replaced by new ones. Spiders retain vials were examined every two days and monitored for moulting, survival and maturity. Life cycle duration was recorded in addition to number of egg sacs and consumed $S$. littoralis larvae.

\section{RESULTS AND DISCUSSION}

\section{Spiders Associated with Cotton and Maize Plants} in Sharkia Governorate:

Table, 1 shows that eighteen spider species belonging to nine families were collected.

Obtained data revealed that the most frequently species were Thomisus spinifer Cambridge ,
Cheiracanthium isiacum Cambridge . K unlica. Thanatus albini (Audouin) and Plexippus pakulli (Audouin). Their percentages of absolute frequency occurrence were $100.00,61.11,55.55,50.00$, and $44.44 \%$, respectively, while their relative frequency occurrence were $20.47,12.51,11.37,10.23$ and 9.09 $\%$, respectively. Former group was followed by Erigone dentipalpis (Wider), Argiope sp., Prinerigone vegans (Savigny), Dictyna sp.. Peucetia $\mathrm{sp}$. and Thyene imperials (Rossi) which were represented with more or less similar values of absolute and relative frequencies of occurrence with range from 16.66 to $27.77 \%$ for absolute and 3.44 to $5.68 \%$ for relative frequency of occurrence. The spider species, Erigone sp., Gnathonarium dentatum (Wider), Prinerigone sp., Thanatus sp., Philodromus sp., Euryopis sp. and Cyrtophora citricola (Forskal) were represented by the lowest percentages of frequency occurrence with range of 5.5 to $11.11 \%$ for absolute and 1.13 to $2.27 \%$ for relative frequency of occurrence, respectively.

Table (1): Spiders collected from cotton and maize plants during 2009 season at Sharkia Governorate

\begin{tabular}{|c|c|c|c|}
\hline Spider species & $\begin{array}{l}\text { No. of samples } \\
\text { containing } \\
\text { the species }\end{array}$ & $\begin{array}{c}\text { Absolute } \\
\text { frequency } \\
\text { occurrence \% }\end{array}$ & $\begin{array}{c}\text { Relative } \\
\text { frequency } \\
\text { occurrence } \%\end{array}$ \\
\hline \multicolumn{4}{|l|}{ Fam. Theridiidae Sundevall } \\
\hline Kochiura aulica Koch & 10 & 55.56 & 11.37 \\
\hline Euryopis sp. & 1 & 5.56 & 1.14 \\
\hline \multicolumn{4}{|l|}{ Fam. Linyphiidae Blackwall } \\
\hline Erigone sp. & 1 & 5.56 & 1.14 \\
\hline E dentipalpis (Wider) & 5 & 27.78 & 5.68 \\
\hline Gnathonarium dentatum (Wider) & 1 & 5.56 & 1.14 \\
\hline Prinerigone sp. & 2 & 11.11 & 2.27 \\
\hline P. vegans (Savigny) & 4 & $22 . \overline{22}$ & 4.55 \\
\hline \multicolumn{4}{|l|}{ Fam. Araneidae Clerck } \\
\hline Cyrtophora citricola (Forskal) & 1 & 5.56 & 1.14 \\
\hline Argiope sp. & 5 & 27.78 & 5.68 \\
\hline \multicolumn{4}{|l|}{ Fam. Oxyopidae Thorell } \\
\hline Pencetia sp. & 3 & 16.66 & 3.41 \\
\hline \multicolumn{4}{|l|}{ Fam. Dictynidae Cambridge } \\
\hline Dictyna sp. & 3 & $16.6 \overline{6}$ & 3.41 \\
\hline \multicolumn{4}{|l|}{ Fam. Miturgidae Simon } \\
\hline $\begin{array}{l}\text { Cheiracanthium isiacum } \\
\text { Cambridge }\end{array}$ & 11 & 61.11 & 12.50 \\
\hline \multicolumn{4}{|l|}{ Fam. Philodromidae Thorell } \\
\hline Thanatus sp. & 1 & 5.56 & 1.14 \\
\hline T. albini (Audouin) & 9 & 50.00 & 10.23 \\
\hline Philodromus sp. & 2 & 11.11 & 2.27 \\
\hline \multicolumn{4}{|l|}{ Fam. Thomisidae Sundevall } \\
\hline Thomisus spinifer Cambridge & 18 & 100.00 & 20.45 \\
\hline \multicolumn{4}{|l|}{ Fam. Salticidae Blackwall } \\
\hline Plexippus paykulli (Audouin) & 8 & 44.44 & 9.09 \\
\hline Thyene imperials (Rossi) & 3 & 16.66 & 3.41 \\
\hline
\end{tabular}


Table, 2 shows frequency of occurrence for spiders associated with cotton and maize. Eight species were collected from cotton fields. The most abundant species were Thomisus spinifer followed by $K$ aulica, E. dentipalpis, $P$. vagans, $P$. paykulli, C. isiacum, Philodromus sp. and C. citricola. Their percentages of absolute and relative frequencies of occurrence in the total samples were collected from cotton fields with range from 100 to $11.11 \%$ for absolute frequency of occurrence and from 3.45 to $31.04 \%$ for relative frequency of occurrence.

On maize, sixteen spider species were collected. The most abundant species were $C$. isiacum, $T$. albini, and $T$. spinifer, while their absolute and relative frequencies of occurrence recorded 100 to $15.25 \%$, respectively. Following those descendingly were by $P$. paykulli, Argiope sp., Thyene imperials, Dictyna sp., $K$. aulica, Peucetia sp., Erigone sp., G. dentatum, P. vagans, Thanatus sp. and Euryopis sp., with percentages of absolute and relative frequency from 11.11 to 66.67 and 1.69 to $10.17 \%$, respectively.

\section{Biological studies:}

Developmental duration of different stages of the theridiid spider $K$. aulica fed on the second instar larvae of $S$. littoralis were studied. Egg incubation period averaged 20 days for both female and male (Table 3), being the longest compared with data published by other workers on theridiid spiders as it ranged between 9.6 to 13.0 days on different preys (the $3^{\text {rd }}$ and $4^{\text {th }}$ larvae of the coleopteran, Tribolium confusum Jacquelin du val; cotton leaf worm S. littoralis; lasser wax moth, Achroia grisella; Tetranychus urticae \& Ahpis craccivora singly or mixture according to Rahil \& Hanna (2001), El-Erksousy et al., (2002), Mohafez (2004), Hussein et al., (2003), respectively.

The spider, $K$. aulica passed through five instars before reaching adulthood for female and male, recording $62.05 \pm 1.16$ and $59.09 \pm 1.51$ days, respectively. Female life cycle was longer than that of male, as it averaged $82.05 \pm 1.16$ days.

Adult female longevity recorded 109.0 7.21 days, including pre-oviposition, oviposition, and post-oviposition averaging $17.00 \pm 6.25,72.33 \pm 6.66$, and 19.67 \pm 7.57 days, respectively (Table 4). Average female deposited $5.00 \pm 0.70$ egg sacs, with $19.33 \pm 2.52$ eggs / each. Thus, total number of eggs/female was $107.6 \pm 3.29$ eggs.

Results showed that $K$. aulica female and male passed through five instars which recorded longer

Table (2): Frequency occurrence of spiders associated with cotton and maize plants during 2009 season at

Sharkia Governorate.

\begin{tabular}{|c|c|c|c|c|c|c|}
\hline \multirow[b]{2}{*}{ Spider species } & \multicolumn{3}{|c|}{ Cotton $(\mathrm{N}=9)$} & \multicolumn{3}{|c|}{ Maize $(\mathrm{N}=9)$} \\
\hline & No. & $\begin{array}{c}\text { Absolute frequency } \\
\text { occurrence } \%\end{array}$ & $\begin{array}{c}\text { Relative frequency } \\
\text { occurrence } \%\end{array}$ & No & $\begin{array}{c}\text { Absolute frequency } \\
\text { occurrence } \%\end{array}$ & $\begin{array}{c}\text { Relative frequency } \\
\text { occurrence } \%\end{array}$ \\
\hline Erigone sp. & 0 & 0.0 & 0.0 & 1 & 11.11 & 1.69 \\
\hline E. dentipalpis & 3 & 33.33 & 10.34 & 2 & 22.22 & 3.39 \\
\hline Gnathonarium dentatum & 0 & 0.0 & 0.0 & 1 & 11.11 & 1.69 \\
\hline Prinerigone sp. & 0 & 0.0 & 0.0 & 2 & 22.22 & 3.39 \\
\hline P. vagans & 3 & 33.33 & 10.34 & 1 & 11.11 & 1.69 \\
\hline Plexippus paykulli & 2 & 22.22 & 6.89 & 6 & 66.67 & 10.17 \\
\hline Thyene imperials & 0 & 0.0 & 0.0 & 3 & 33.33 & 5.08 \\
\hline Cheiracanthium isiacum & 2 & 22.22 & 6.89 & 9 & 100 & 15.25 \\
\hline Dictyna sp. & 0 & 0.0 & 0.0 & 3 & 33.33 & 5.08 \\
\hline Thanatus sp. & 0 & 0.0 & 0.0 & 1 & 11.11 & 1.69 \\
\hline T. albini & 0 & 0.0 & 0.0 & 9 & 100 & 15.25 \\
\hline Philodromus sp. & 2 & 22.22 & 6.89 & 0 & 0.0 & 0.0 \\
\hline Thomisus spinifer & 9 & 100 & 31.04 & 9 & 100 & 15.25 \\
\hline Kochiura aulica & 7 & 77.77 & 24.14 & 3 & 33.33 & 5.08 \\
\hline Euryopis sp. & 0 & 0.0 & 0.0 & 1 & 11.11 & 1.69 \\
\hline Peucetia sp. & 0 & 0.0 & 0.0 & 3 & 33.33 & 5.08 \\
\hline Cyrtophora citricola & 1 & 11.11 & 3.45 & 0 & 0.0 & 0.0 \\
\hline Argiope sp. & 0 & 0.0 & 0.0 & 5 & 55.56 & 8.48 \\
\hline
\end{tabular}

$\mathrm{N}=$ Number of collected samples.

No. $=$ Number of samples containing a species. 
Table (3): Duration of $K$. aulica different spiderlings in days fed on $S$. littoralis $2^{\text {nd }}$ instar larvae at $28 \pm 1^{\circ} \mathrm{C} \&$ $60-70 \%$ R.H.

\begin{tabular}{lcccccc}
\hline \multirow{2}{*}{ Spider stages } & \multicolumn{4}{c}{ T } & \multicolumn{3}{c}{ है } \\
\cline { 2 - 7 } & Min. & Max. & Mean \pm S.D. & Min. & Max. & Mean \pm S.D. \\
\hline Egg incubation & 20 & 20 & $20.00 \pm 0.0$ & 20 & 20 & $20.00 \pm 0.0$ \\
\hline $1^{\text {st }}$ instar & 12 & 22 & $15.62 \pm 2.5$ & 13 & 18 & $15 \pm 2.14$ \\
\hline $2^{\text {nd }}$ instar & 11 & 16 & $12.38 \pm 1.32$ & 10 & 16 & $11.73 \pm 1.85$ \\
\hline $3^{\text {rd }}$ instar & 7 & 16 & $12.05 \pm 2.06$ & 12 & 16 & $12.82 \pm 1.25$ \\
\hline $4^{\text {th }}$ instar & 10 & 16 & $11.57 \pm 1.69$ & 7 & 12 & $9.09 \pm 1.97$ \\
\hline $5^{\text {th }}$ instar & 7 & 16 & $12.71 \pm 2.57$ & 11 & 16 & $12.82 \pm 1.88$ \\
\hline Total spiderlings & 60 & 63 & $62.05 \pm 1.16$ & 55 & 60 & $59.09 \pm 1.51$ \\
\hline Life cycle & 80 & 83 & $82.05 \pm 1.16$ & 75 & 80 & $79.09 \pm 1.51$ \\
\hline
\end{tabular}

Table (4): Adult female longevity and fecundity of $K$ aulica fed on the $2^{\text {nd }}$ instar larvae of $S$. littoralis at $28 \pm 1{ }^{\circ} \mathrm{C} \& 60-70 \%$ R.H.

\begin{tabular}{lc}
\hline \multicolumn{1}{c}{ Spider female stages (days) } & Mean \pm S.D. \\
\hline Pre-ovipostion period & $17.00 \pm 6.25$ \\
\hline Ovipostion period & $72.33 \pm 6.66$ \\
\hline Post-ovipostion period & $19.67 \pm 7.57$ \\
\hline Longevity & $109.0 \pm 7.21$ \\
\hline Mean number of eggs/egg sac & $19.33 \pm 2.52$ \\
\hline Mean total egg sacs/female & $5.00 \pm 0.70$ \\
\hline Total number of eggs/female & $107.6 \pm 3.29$ \\
\hline
\end{tabular}

Results showed that $K$. aulica female and male passed through five instars which recorded longer durations $(62.05 \pm 1.16 \& 59.09 \pm 1.51$ days at $28 \pm$ $1{ }^{\circ} \mathrm{C} \& 60-70 \%$ R.H.) compared with that obtained by El-Erksousy et al. (2002), on Anelosemus aulicus recording 47.2 and 44.2 days for female and male, respectively, when fed on $S$. littoralis larvae, without mention prey instar, at $26 \pm 2{ }^{\circ} \mathrm{C}$ and $60-70 \%$ R.H. Both sexes of $A$. aulicus spiderlings lasted for 33.33 and 32.62 days, respectively, when fed on $3^{\text {rd }}$ and $4^{\text {th }}$ larvae of T. confusum at $27 \pm 1^{\circ} \mathrm{C}$ and $57.7 \%$ R.H. (Rahil \& Hanna, 2001).

\section{Feeding capacity:}

All stages of the spider $K$. aulica fed on the second instar larvae of the cotton leafworm, $S$. littoralis. Its feeding capacity generally increased parallel with the progress of spider development from first to fifth instars. Mean number of consumed prey for the first instar was $101.52 \pm 3.53$ and $100.73 \pm 3.29$ prey individuals, for female and male, respectively, while it increased to $199.95 \pm 3.80$ and $191.36 \pm 4.43$ for the fifth instar, respectively. The mean number of devoured prey individuals for total spiderlings was $599.52 \pm 7.73$ and $591.64 \pm 7.17$, for female and male, respectively (Table, 5 ).
Table (5): Feeding capacity of $K$. aulica different spiderlings fed on S. littoralis $2^{\text {nd }}$ instar larvae.

\begin{tabular}{|c|c|c|c|c|}
\hline \multirow{3}{*}{ Stages } & \multicolumn{4}{|c|}{$\begin{array}{l}\text { Mean number of consumed } S \text {. littoralis } 2^{\text {nd }} \\
\text { instar larvae }\end{array}$} \\
\hline & 9 & & $\hat{i}$ & \\
\hline & $\begin{array}{l}\text { Mean } \pm \text { S.D. } \\
\text { (Min. - Max.) }\end{array}$ & $\begin{array}{l}\text { Daily } \\
\text { mean }\end{array}$ & $\begin{array}{l}\text { Mean } \pm \text { S.D. } \\
\text { (Min. - Max.) }\end{array}$ & $\begin{array}{l}\text { Daily } \\
\text { mean }\end{array}$ \\
\hline $1^{\text {st }}$ instar & $\begin{array}{c}101.52 \pm 3.53 \\
(100-115)\end{array}$ & 6.49 & $\begin{array}{c}100.73 \pm 3.29 \\
(95-105)\end{array}$ & 5.04 \\
\hline $2^{\text {nd }}$ instar & $\begin{array}{l}60.05 \pm 4.13 \\
(55-70)\end{array}$ & 4.49 & $\begin{array}{l}57.82 \pm 2.52 \\
55-60\end{array}$ & 3.21 \\
\hline $3^{\text {rd }}$ instar & $\begin{array}{l}68.00 \pm 3.66 \\
(60-72)\end{array}$ & 5.64 & $\begin{array}{c}69.27 \leq 2.19 \\
65-72\end{array}$ & 4.46 \\
\hline $4^{\text {th }}$ instar & $\begin{array}{l}170.48 \pm 3.50 \\
(165-180)\end{array}$ & $\begin{array}{c}13.4 \\
6\end{array}$ & $\begin{array}{c}168.64 \pm 4.52 \\
155-170\end{array}$ & 14.05 \\
\hline $5^{\text {th }}$ instar & $\begin{array}{c}199.95 \pm 3.80 \\
(196-215)\end{array}$ & $\begin{array}{c}15.7 \\
3\end{array}$ & $\begin{array}{c}191.36 \pm 4.43 \\
(186-200)\end{array}$ & 10.63 \\
\hline $\begin{array}{l}\text { Total } \\
\text { spiderlings }\end{array}$ & $\begin{array}{c}599.52 \pm 7.73 \\
(590-620)\end{array}$ & 9.88 & $\begin{array}{c}591.64 \pm 7.17 \\
575-600\end{array}$ & 10.03 \\
\hline
\end{tabular}

\section{ACKNOWLEDGEMENT}

The authors are indebted to Col. Hisham K El-Hennawy (Cairo) who identified the reared spider species and kindly revised a draft of the manuscript.

\section{REFERENCES}

Abdel-Karim, E. H.; Rady, G. H. H.; Ibraheem, G. A. and Ahmed, Naglaa F. R. 2006. Biology, mass rearing and observations on the behaviour of Kochiura aulica (C. L. Koch, 183) (Arachnida: Aranida: Theridiidae). Serket, 10(1): 35-43.

Asin, L. and Pons X. 1996. Studies on ecology and control of maize aphids in Catalonia Bull., OllB. SROP, 19 (3): 77-82.

El-Erksousy, M,H; Shoeib, A.A. and Dahi, H.l. 2002. Studies on biological control using the spider, Anelosimus aulicus (Theridiidac). Proc. 
$2^{\text {nd }}$ Internat. Conf.. Plant Protection Research Institute, Cairo, Egypt. 1:1-2.

El-Hennawy, H.K. 2002. The Egyptian Arachnids. Publication no. 12 of National Biodiversity Unit, Egyptian Environmental Affairs Agency (EEAA), Nature Conservation Sector. 110 pp., 16 colour plates (In Arabic).

El-Hennawy, H. K. 2006. A list of Egyptian spiders. Serket, 10(2):65-76.

Hussein, A.M.; Hassan, M.F.\& Ahmad, N.F.R. 2003. Biological aspects of Anelosimus aulicus (C.L.Koch, 1838) (Arachnida: Araneida: Theridiidae) in Egypt. Serket, 8(4): 129-134.

Kamal, N. Q.; Karim A. N.; Rahim K.; Rabbi M. F. and Khan A. K. 1995. Distribution pattern and sampling of rice hispa, brown planthopper, green leafhopper and some rice field predators. Bangladesh J. of Ent., 5(1-2): 41- 48.

Mohafez, M.A.M., 2004. Ecological and biological studies on spiders in Egypt. Ph.D. Thesis, Fac. of
Agric., Al-Azhar Univ., 178pp.

Norton, D.C. 1978. Ecological of plant parasitic nematodes. Wiely, New York, $268 \mathrm{pp}$.

Nyffeler, M.; Sterling W. L. and Dean D. A. 1994. Insectivorous activities of spiders in United States field crops. J. Appl. Entomol., 118(2): 113-128.

Platnick, N. I. 2010. The world spider catalog, version 10.5. The American museum of natural History, website online at.http://research.amnh. org/iz/spiders/catalog.

Rahil, A. A. R. 2001. Relationship between field population of true spiders and pests of maize at Fayoum Governorate. Conf. of Sus. Agric. Devel., Fayoum Fac. of Agric., 185-194.

Rahil, A. A. R. and Hanna, M.A. 2001.Some biological aspects of the true spider, Anelosimus aulicus (Arachnida: Theridiidae). Conf. of Sustainable Agricultural Development, Fac. of Agric., Fayoum Univ., 195-201. 